\title{
2 次元氾濫計算を用いた サモア・アピア市街地の汇濫に関する考察 2D CALCULATION STUDY OF FLOOD DAMAGE IN URBAN AREA AT APIA, SAMOA ISLAND.
}

\author{
岩田圭佑 ${ }^{1} \cdot$ 清水康行 $^{2}$ \\ Keisuke IWATA, Yasuyuki SHIMIZU \\ 1 学生員 北海道大学大学院工学研究科（T060-0808 札幌市北区北 13 条西 8 丁目） \\ 2 正会員 工博 北海道大学教授 北海道大学大学院工学研究科 (同上)
}

\begin{abstract}
River flooding, especially flash floods are a well known risk in Samoa where steep river catchments get frequent intense rainfall events especially in the wet season resulting in floods. On the other hand, there is few information about hydrological observation and flood control is not enough to prevent damages. Therefore, it is very important to predict the flood flow and the danger of the flood during such disaster. This paper will discuss the application of numerical simulation models to the rivers which flows through urban area of Apia. In this study, runoff model and flood calculation are combined to know characteristics of each flood Models have been used to simulate the flood propagation and thus verified against physical observations. The results have identified the inundated area and quantified flood hazard extent and intensity Future studies include fitting flood structures for flood mitigation measures.
\end{abstract}

Key Words : flood calculation, discharge, urban formation

\section{1. はじめに}

サモアの首都アピアでは，例年雨季に入ると都市部を 流れる複数の河川が汇濫し, 大きな被害が発生している. 近年では, 2001 年の 4 月 15-16 日にかけての大雨の影響 により, 都市部が大きな被害を被っている. また 2003 年 や2006 年にも同様の汇濫が発生しており, このような汇 濫に備えて水の流れや汇濫による危険性を知ることがと ても重要な課題となっている. 汇濫の特徴として, 複数 の河川がアピアの市街地や近郊を流れ太平洋に注いでお り，かつ市街地が太平洋に面して形成されていることか ら, 汇濫は単一河川ではなく複数の河川の影響を受ける と考えられ，さらには潮位による影響も考慮しなければ ならない. その一方で, それらの検討に必要な降雨量や 流量といった水理・水文資料がそしく, 治水整備などが 十分に行われているとは言いがたい，また，過去の洪水 の歴史的な資料も乏しいため, 汇濫の全体像をつかむこ とは非常に困難である.

そこで本研究では, 第一に 2001 年 4 月汇濫を例に取り,
流出解析で得られた流量を基に数值解析を行い汇濫を再 現し，その特徵を考察することで，複数の河川が汇濫す ることによる, 洪水時間全体の汇濫の様子を明らかにす ることを目的とする. 計算結果の検証は, 現地での聞き 込みや調查結果，参考資料を基に行った.

また，これによって確立された数值計算を用いること で, 対象地域の地形特徵に基づく汇濫の様子についての 考察や, 汇濫と土地利用の関係性についての初期的な考 察を行うこととする.これにより, 将来の治水対策への 活用だけでなく, 歴史的な資料が不足している中で過去 の汇濫を可視化し，過去の洪水に対してこの地域がどの ような影響を受けてきたのかということや，土地利用の 形態, 都市形成と汇濫特性の関係性を見出寸ための重要 な手がかりになり得ると考える.

流出解析については各種パラメータを確定する調査が 不十分であったため, 簡単な貯留関数法を用い流量を決 定した. また, 2 次元の汇濫解析については, 衛星による

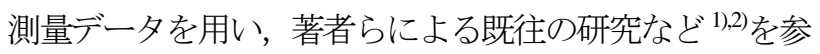
考に行った. 近年, 衛星による地形測量技術が発達し, 
本研究のように数值計算にも積極的に用いられるように なってきたが，低水路部においては水面位が標高データ となってしまうため，それが計算結果の信用性にどれほ どの影響を与えるのかを考える必要がある。これは，河 道横断形状が測量できない河川の汇濫計算を行う上で重 要な問題であり, 本研究ではこれについての考察を加え た上で全体の考察を行った.

\section{2. 現地の状況}

\section{（1） 解析対象地}

解析対象地は，サモア・ウポル島の首都アピアを流れ る複数の河川とその流域と寸る. 図一1 は解析対象地の位

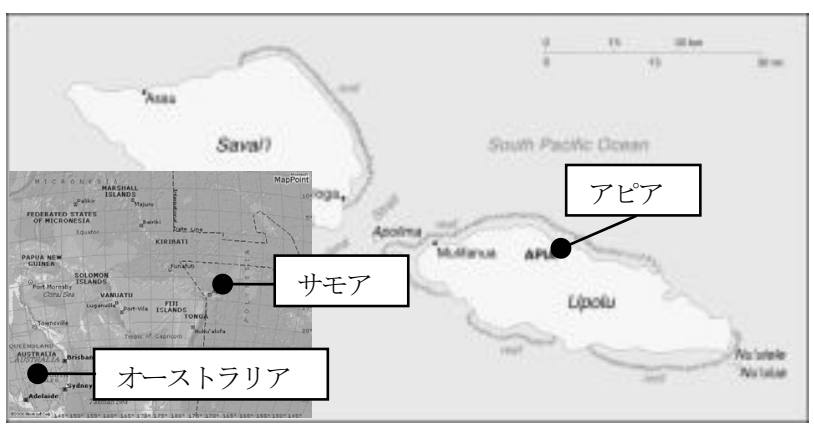

図ー1アピア位置図

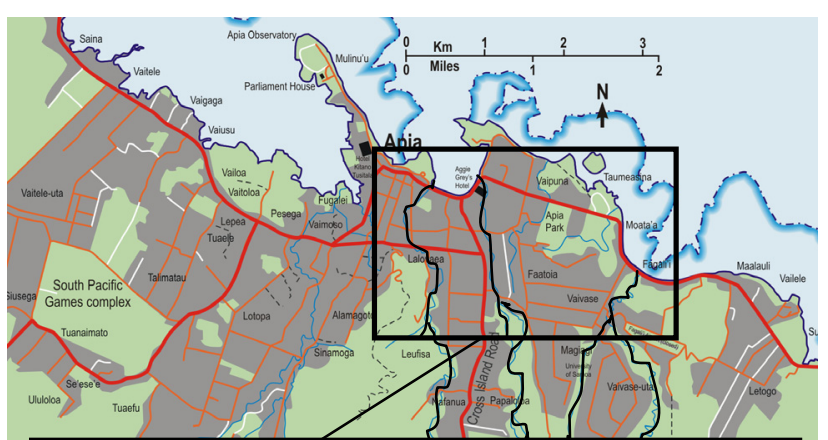

計算範囲

(左から Vailima 川, Visigano 川, Vaivase 川) 図一2 アピア市街地と解析対象地

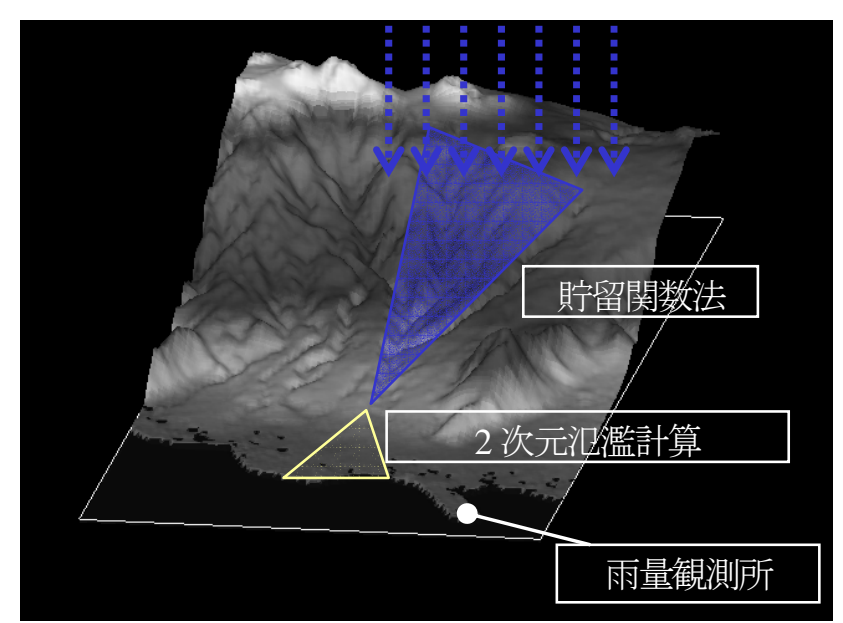

図-3 計算法模式図
置を示し, 図一2 は解析対象地点の拡大図である. 対象河 川には, 市街地を流れる中で最も流域面積の広い Visigano 川と，その西隣にある，流域面積は狭いが都市部を流れ 汇濫被害の出た Vailima 川, さらに, 東隣にある Vaivase 川を選んだ. Vaivase 川を選んだ理由は, Visigano 川の治 水対策として, 本川から東に分岐して沼地に至る放水路 を建設する計画があがっており, Vaivase 川が汇濫してこ の沼地に影響を与えるようなことがあれば，それを考慮 した計画にしなければならず，検討要素として加えてお くべきと考えたためである.

\section{（2） 汇濫の概要}

2001 年 4 月 15 日から 16 日にかけて，4 時間ほどの間 に約 200mm の降雨が計測され, 北部の海岸に沿った地域 を中心に汇濫が広がったと推測されている.この汇濫に より道路や水道管などインフラが大きな被害に遭い, 5000 人が住居の被害を受け，28000 人が断水の影響を受 けたとされる.この氾濫では Apia を含む東西約 $10 \mathrm{~km} の$ 範囲にある 5 河川が汇濫したとされており, その特徴と して,「外水汇濫と内水汇濫の複合的なものであったこ と」「流速が速かったこと」「鉄砲水のような現象があっ たこと」などが挙げられているが，それが具体的にどこ でどのように発生したのかは述べられていない3. 地形か ら考えると, 背後に急峻な山地が広がっており, 市街地 はその下流の扇状地のような地形上に形成されているこ とから，上流部の山地に降った雨が短時間のうちに河川 流となり市街地に達し, 広域で氾濫が広がったものと推 測できる. Visigano 川を例にとると，流域最高部の標高は $1000 \mathrm{~m}$ 以上に達しており, 河口までの距離は $12.5 \mathrm{~km}$ であ るため，このようにそれぞれの河川が非常に急勾配な地 形状を流れて市街地に達することが，対象流域における 氾濫の大きな特徵であるといえる. 本研究では, 以上の 参考文献に述べられていた情報や，対象領域の特徽を踏 まえ結果の考察を行う。

\section{3. 解析方法}

図-3に今回の一連の計算の模式図を示す，対象河川 において，汇濫時に継続的な流量観測は行われていなか ったため, 降雨量のデータを基に流出解析を行いそれぞ れの河川の流量を求め, それらを上流端へのインプット として 2 次元の氾濫計算を行った. 上流端の境界につい ては，流量をインプットするそれぞれの断面を指定し， 平均地盤高と勾配をもとに繰り返し計算でそれぞれの断 面の初期水位, 流量を求めた。 また, 下流端の境界条件 としては同時刻に計測されていた潮位を与えた.

\section{（1） 流出解析}

先に述べたように，それぞれの河川の流量を現地の降 


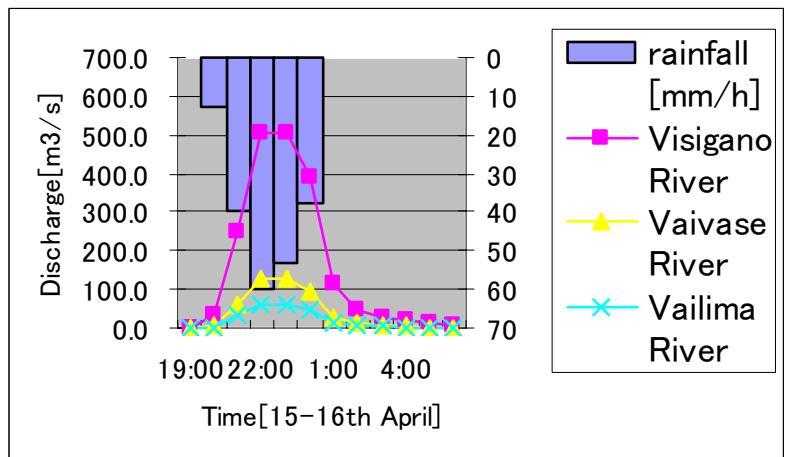

図-4 上流端流量

雨データを基に貯留関数法から求めた. 用いた連続式と 貯留関数式をそれぞれ以下に示す.

$$
\begin{aligned}
& \frac{d s}{d t}=f r-q \\
& s=K q^{p}
\end{aligned}
$$

ここで, $s:$ みかけの貯留高, $K, p:$ 係数, $q$ : 流出高, $f$ : 流出率, $r$ : 降雨量, $t$ : 時間である. 係数は $K=$ 5.0, $p=0.6$ を, 流出率には $f=1.0, \Delta t=0.1$ として計算を 行った. 流出率については, 表面の土地利用や地層構造 を基に検討して与えるべきであったが，水文資料が少な く検討できないこと，地層構造を把握しておらず，降雨 量以外の要素を含む $f=1.0$ 以上において検討材料がないこ と，1.0 付近の值を用いることで今回の目的に対して十分 な考察ができること，などを理由にこの流出率を用いた. また, 同様の理由で, 遅れ時間は考慮していない, 流域 面積は 3 秒メッシュの衛星地形測量データを用いて，落 水線をたどり合計の面積を求めることによりその川の流 域面積とし, Visigano 川で $34.2 \mathrm{~km}^{2}$, Vailima 川で $4.3 \mathrm{~km}^{2}$, Vaivase 川で $8.6 \mathrm{~km}^{2}$ として流量を求めた. 求められた流量 を図一4 に示す. 参考文献 4,5)では, Visigano 川の流量に ついてアピア近郊や上流部で流出解析が行われており, 最大流量は約 $530 \mathrm{~m}^{3} / \mathrm{s}$ という結果が得られている. 今回求 められた流量もこれに近い值が得られているため, 本研 究ではこの結果を適用することとした.

\section{（2） 氾濫解析}

計算は 2 次元非定常流, 非圧縮流れの連続式および運 動方程式をもとに行った. 詳細は前出の参考文献 1),2) に譲 る. 基礎式を以下に示す.

連続式

$$
\frac{\partial h}{\partial t}+\frac{\partial(u h)}{\partial x}+\frac{\partial(v h)}{\partial y}=0
$$

$x$ 方向運動方程式

$$
\begin{aligned}
& \frac{\partial(u h)}{\partial t}+\frac{\partial\left(u^{2} h\right)}{\partial x}+\frac{\partial(u v h)}{\partial y} \\
& =-g h \frac{\partial H}{\partial x}-\frac{\tau_{x}}{\rho}+\frac{\partial}{\partial x}\left[v_{t} \frac{\partial(u h)}{\partial x}\right]+\frac{\partial}{\partial y}\left[v_{t} \frac{\partial(u h)}{\partial y}\right](3 a)
\end{aligned}
$$

$y$ 方向運動方程式

$$
\begin{aligned}
& \frac{\partial(v h)}{\partial t}+\frac{\partial(u v h)}{\partial x}+\frac{\partial\left(v^{2} h\right)}{\partial y} \\
& =-g h \frac{\partial H}{\partial x}-\frac{\tau_{y}}{\rho}+\frac{\partial}{\partial x}\left[v_{t} \frac{\partial(v h)}{\partial x}\right]+\frac{\partial}{\partial y}\left[v_{t} \frac{\partial(v h)}{\partial y}\right]
\end{aligned}
$$

ここで, $x, y$ : 格子座標, $u, v: x, y$ 方向の水深平均流, $t$ : 時間, $\rho$ : 水の密度, $g$ : 重力加速度, $h:$ 水深, $H:$ 水位 である.また，渦動粘性係数は

$$
v_{t}=\frac{1}{6} \kappa u_{*} h
$$

である.ここで $\tau_{x}, \tau_{y}$ は $x, y$ 方向の河床せん断力で

$\tau_{x}=\frac{\rho g n_{m}^{2} u \sqrt{u^{2}+v^{2}}}{h^{\frac{1}{3}}}, \tau_{y}=\frac{\rho g n_{m}^{2} v \sqrt{u^{2}+v^{2}}}{h^{\frac{1}{3}}}$

で表される. マニングの粗度係数 $n_{m}$ は底面の土地利用状 況に応じて変化させるべきであるが，詳細な建築物や植 生の密度などといったデータが不足しているため, 土地 利用状況に応じた粗度係数を与えることは難しいと考え た. そこで, 現地の河川周辺の状況と航空写真などから 判断し, $n_{m}$ は 0.05 で与えた. また, 時間刻み $\Delta t$ は 0.005 秒で与えた.

\section{4. 計算格子}

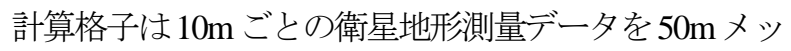
シュに加工したものを用いた. 計算範囲は南北 $2.1 \mathrm{~km}$, 東 西 $3.1 \mathrm{~km}$ である. 計算範囲の鳥瞰図を図一5 に示す. 衛星 地形測量データでは, 水面下の河道形状は測量されてい ないため, 水面が標高地として測量される. それが解析 結果に与える影響については7 章で考察を行っている.

\section{5. 解析システム}

本研究の解析における格子作成や解析結果の可視化を

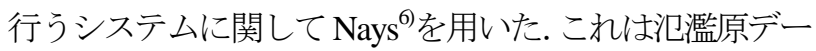
タを読み込み自由に格子を作成し，プログラムで計算を 行った解析結果データを 2 次元または 3 次元で可視化す るというものである. システムの流れを図ー6に示す.

\section{6. 計算結果}

計算は午後 9 時から翌午前 4 時までの 7 時間にわたり 行われた. 午後 9 時から計算を開始し, 上流端から求め られた流量を与えて計算を進めた. 水深コンターの時間 変化を図一7,8,9,10 に示寸. 午後 9 時 30 分においてはす でに汇濫が広がり始めている様子がわかる．また，放水 


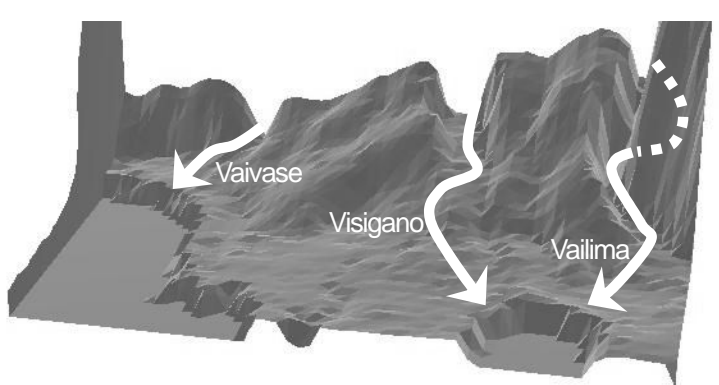

図-5＼cjkstart計算対象地鳥瞰図

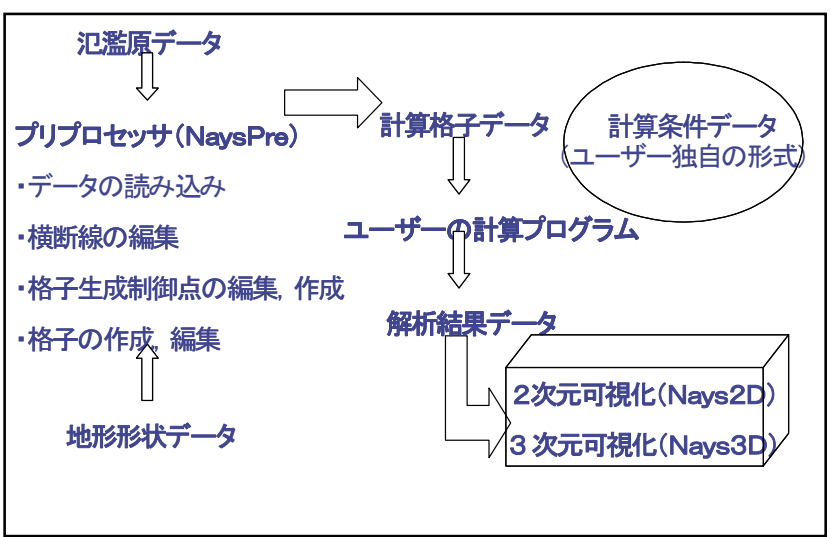

図－6 解析方法と可視化の流れ

路が計画されている Visigano 川本流から沼地方面にかけ ても汇濫が同時に広がっていく様子が伺えた．これによ り，このエリアに放水路を造れば，放水と流量カットが 的確に行えることを計算結果でも示寸ことができたと言 える.

午前 0 時 30 分頃には水深が最大となり, 市街地と沼地 が冠水している様子がわかる. また，放水路計画に影響 を与えると考えられた Vaivase 川の汇濫に関しては, 流速 ベクトルを検討した結果, 沼地一若干の流入が見られる ものの Visigano 川からの流入量が支配的であることがわ かった. 一方 Vailima 川と Visigano 川の汇濫については, 今回の計算結果では流量の交換は見られず，氾濫域は独 立していることがわかった。

午前 3 時になると, Visigano 川と Vaivase 川に沿った地 域の汇監は引いているのに対し, 沼地や Vailima 川下流部 においては水深の変化がほとんど見られなかった。

Visigano 川については, 'The flood rose at about 9:30 pm and was reported to have receded from most affected properties by 3am.’ と述べられており 7), Visigano 川における汇濫の再現 性は良好であると言える。

一方で, Vailima 川下流部と沼地については，7 時間が 経過した後も汇濫が引く様子は見られなかった. 図一11 に計算範井における $1 \mathrm{~m}$ ごとの地盤高コンター図を示す. Vailima川下流側や沼地は周囲より標高が低く水が溜まり や寸い地形になっていることがわかる. Vailima川はこの 低地を右岸側に見て迂回寸るように流れており, 1 度水が 溢れこの低地に汇濫が広がると, 排水性に乏しく長時間

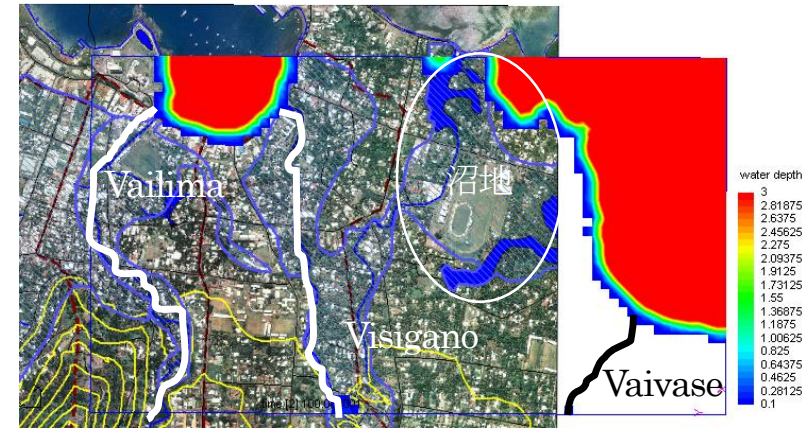

図-7 午後 9 時 (計算開始)

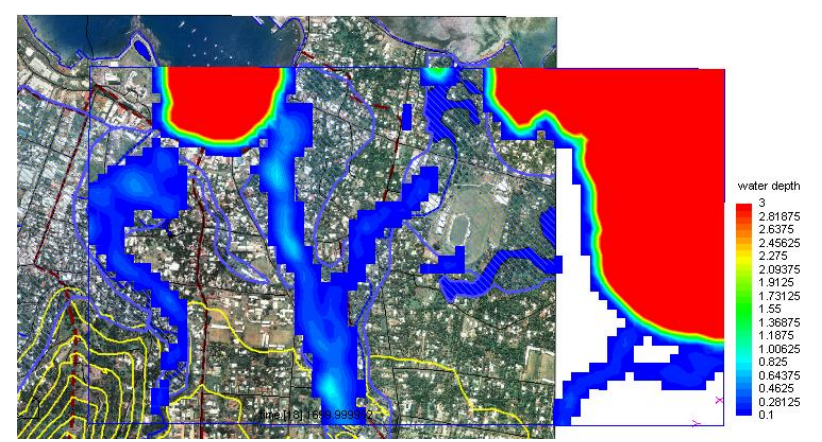

図-8 午後 9 時 30 分 水深コンター

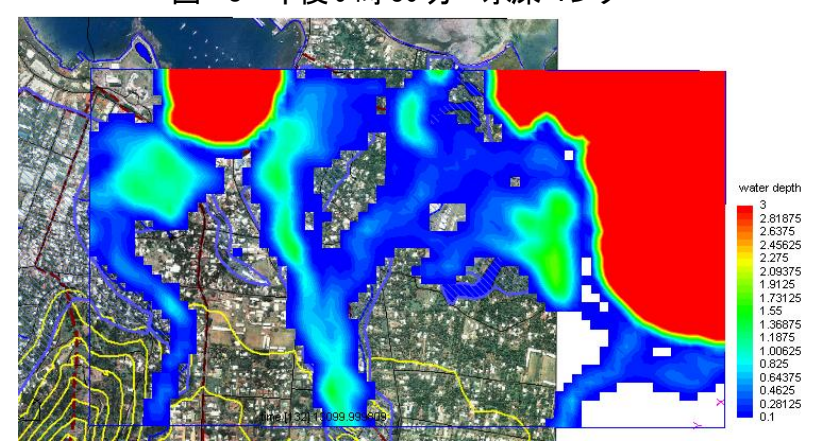

図-9 午前0 時 30 分 水深コンター

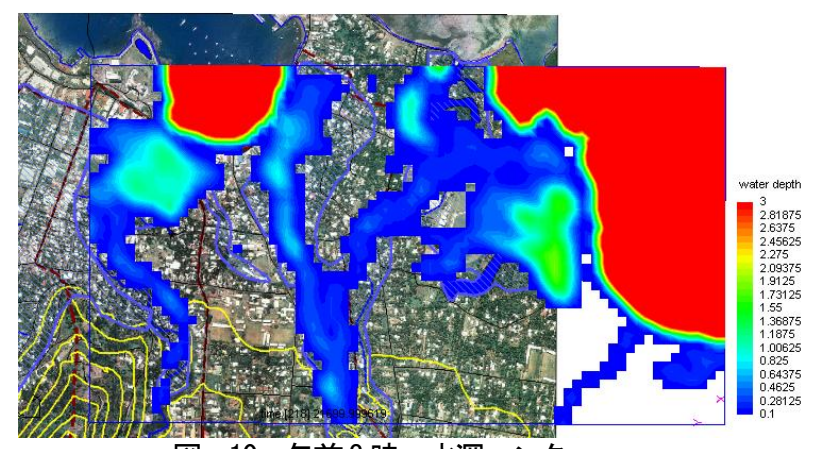

図-10 午前 3 時 水深コンター

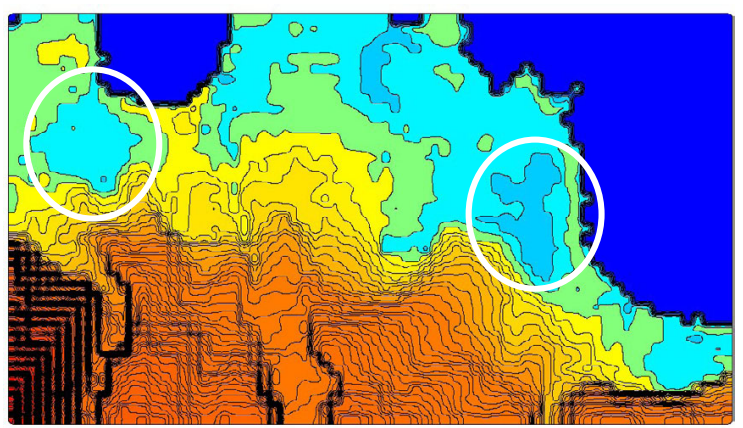

図-11 1m ごとの地盤高コンター図 


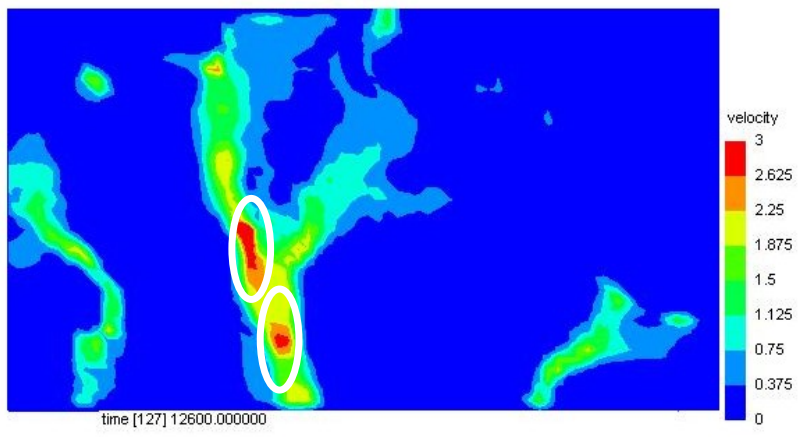

図-12 午前0 時 30 分 流速コンター図

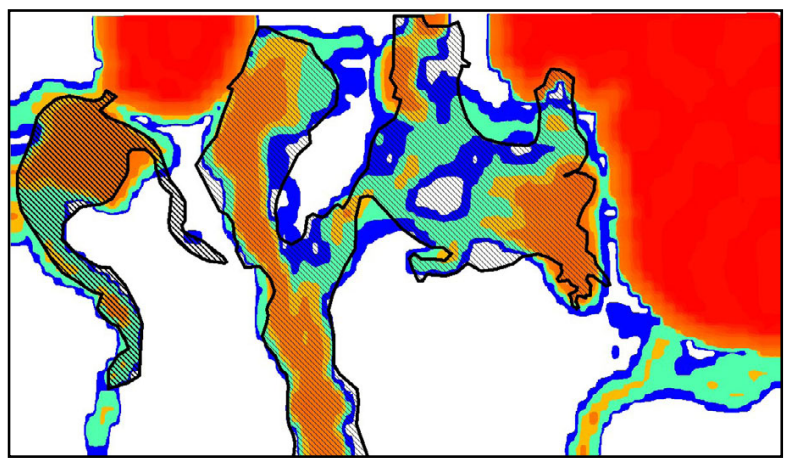

図-13 実績汇濫との比較

の被害が予想される.この地は現在学校のグラウンドと して使用されているが，左岸側にはアピアの市街地が形 成されており, 都市のインフラ, 特に下水などに悪影響 を与えると考えられる. 排水性の悪さは当初，湾内の海 岸沿いに建設された堤防が原因の 1 つではないかと考え られていたが，これに加えて元々の地形的な特徵が排水 性に支障をもたらしていることが計算結果からも再現で きた.

次に, 2-(2)で述べた氾濫の概要に基づいた考察を行う. 「外水汇濫と内水汇濫の複合的なものであったこと」に ついては，まだ今回の計算方法では具体的な検討ができ る段階ではなく, 今後の検討課題である。「流速が速かっ たこと」「鉄砲水のような現象があったこと」については, 図ー12 の流速コンター図にみられるように, Visigano 川 において流速が比較的大きい場所(白円)が見られた. 航空 写真から判別すると, この周辺には他の地域と比較し て建築物が見られず．もともとこのような流速の速い 汇濫に対して市街地が形成されづらい地域であったとい う関係性がうかがえる。

\section{7. 低水路の再現性について}

今回の計算では, 衛星測量による $10 \mathrm{~m}$ ごとの地形デー 夕を $50 \mathrm{~m}$ 置きに抽出して計算格子とした。 そのため細部 の地形形状に関しては再現できていない部分がある. 実 績氾濫域と計算結果の比較を図一13に示寸，黒い太線で 囲んだ範囲が，現地の住民の情報を基に作成した実績氾
濫域 8)である. Vaivase 川については情報が残っていなか った. これによると, Visigano 川の氾濫域は計算によって 概ね再現できていると言える. 一方 Vailima 川については, 汇濫の広がる様子は再現できたが, 下流側で計算結果が 実績氾濫域を超えているのが目立つ。これは, Visigano 川より小さい河川であるため, 同じスケールの格子で計 算した結果再現性に影響が現れたためと考えられる.

よって, 計算結果の信用性を確保するために, 特に河 道の地形形状の再現性が広域の氾濫計算に対してどれほ どの影響があるのかを検討する必要がある.6 章で述べた 通り, Visigano 川の汇濫が他の河川の汇濫から受ける影響 は小さい，そこで, 河道横断測量データの得られた Visigano 川について, 低水路の地形を再現し同じ条件で氾 濫計算を行い, 6 章で述べた衛星地形データを用いた場合 の計算結果と比較し, Visigano 川における汇濫の様子の違 いを検討した. 横断測量データを用いた午後 9 時 30 分と 午前 3 時の計算結果をそれぞれ図一14，15 に示寸，それ ぞれ図ー8, 10 と比較されたい.

まず，全体を通じて最深部の水深が，低水路を再現し たほうがより深く再現されている.これは予想された結 果であり, 衛星データより地形を再現する場合は低水路 の深さデータは失われ，本来より浅く再現されてしまう ためである.

次に，氾濫の広がった範囲について時間ごとに考察す る. 午後 9 時 30 分には下流側で汇濫が広がり始めた様子 がわかり, 先ほどの議論と同様良い再現が出来ていると 思われる。ただ汇濫の広がる範囲は, 衛星地形データを 用いた場合の方が，特に計算範囲内上流部で広くなって いる. また, 午前 3 時の計算結果は, 下流部でも汇濫が 引き水深は浅くなっている. この場合も 9 時 30 分の時と 同様，衛星地形デー夕を用いた場合のほうが広く汇濫が 残ったままになっている.

今回の計算結果を比較すると小流量時には流れの様子 に違いが見られ，大きな影響が考えられるものの，大流 量時には, 流量が小流量時の 10 倍以上であり, 小流量時 の河道断面積が汇濫面積に与える影響は小さくなると考 えられる. 今後は, どれだけの流量が計算結果に対して 影響があるのかを検討することが課題と言える。

以上のことから, 2 つの地形データの間には少なくと も少流量時の汇濫再現性に違いが現れることがわかった. これは，低水路の地形を考慮することが，少流量時には 大きく影響されることが再現された結果であると考えら れる. 一方, Visigano 川と Vailima 川のように, 河道形 状の規模に対して計算に用いる地形データの大きさを考 慮する必要はあるが，大流量による氾濫の広がりを検討 する場合には, 低水路の地形の再現性による影響は小さ いと考えられる.

よって，市街地全体の汇濫域を検討するような場合は 衛星データのみを用いた計算でも十分検討可能であるが, 




図-14 午後 9 時 30 分 水深コンター

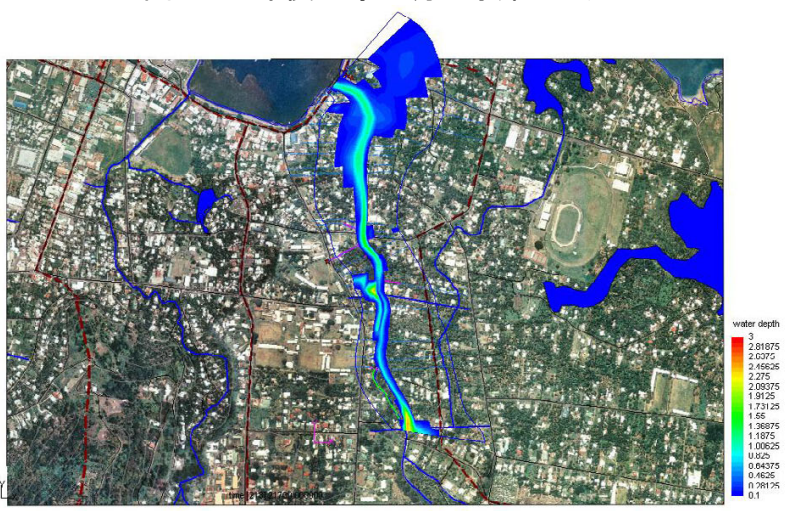

図-15 午前 3 時 水深コンター

河川の沿線に沿った地域の避難情報や災害対策といった 検討には，汇濫が始まる時間や場所といった具体的な情 報が必要になるため, 低水路形状を考慮した汇濫計算が 必要であろう。

\section{8. まとめ}

以上, サモアの首都アピアにおいて, 2 次元氾濫解析モ デルを適用し，複数の河川による汇濫の様子を再現しそ の特徵を考察した. その結果, 以下のことが確認できた.

・氾濫時の流路に放水路を造れば，放水と流量カッ トが的確に行えることを計算結果でも示すことが できた.

・Vailima 川と Visigano 川の汇濫については，今回の 計算結果では流量の交換は見られず，氾濫域は独 立している.

- Vailima 川周辺の市街地では, 地形的な特徴が排水 性に支障をもたらしていることが計算結果からも 再現できた.

・低水路の地形を考慮することが，少流量時には大 きく影響されることが再現された.

今後の研究の課題として, 植生や建築物の影響を考慮 したモデルの性能向上があげられる. さらに，今回の計 算では上流端から同時に流量を与えたが，連続式または 貯留関数式に遅れ時間を考慮するなどの改善すべき点が ある。
氾濫特性と都市形成の関係性についてはまだ歴史的な 議論はできていないが，なぜ地形的に排水性の良い Vaisigano 川流域ではなく, 排水性の悪い Vailima 川流域に 市街地が発展してきたのかという疑問が挙げられる.こ れはあくまで推測に過ぎないが，図一12に見られるよう に Visigano 川の流速は Vailima 川に比べて速く, 頻繁に発 生する洪水から大きな被害を避けるために Vailima 川周 辺から市街地が形成された可能性もある. また, 流速の 速い汇濫に対して市街地が形成されづらい地域があるこ とがうかがえ, 都市形成と汇濫特性の関係性を見出すこ とが今後も期待できる. このように, 汇濫と都市形成, 防災の関係性を考える上で数值計算を用い，汇濫を可視 化することの有用性が得られた.

放水路計画が考えられている湿地周辺には，マングロ 一ブが生息しており, サモアの伝統的高床式住居(ファレ) も多く見られる. 現地の河川は頻繁に発生する洪水によ って土砂堆積が速い速度で進んでいる ${ }^{9}$. 今回の計算では 土砂輸送は考慮されていないが, 放水路計画を進める際 には土砂輸送に関する検討も行い, 湿地の環境に与える 影響について認識する必要がある。これは環境問題のみ ならず, サモア独特の建築物であるファレの保存といっ たことにもつながる問題であるため, 本研究を発展させ て今後も検証していきたい.

\section{参考文献}

1）長谷川善彦，清水康行 : 平成 15 年台風 10 号によ る北海道厚別川の洪水汇濫とその再現計算, 水工 学論文集, 第 49 巻, 2005.

2）岩田圭佑, 清水康行 : 沙流川の汇濫シュミレーシ ヨン, 土木学会北海道支部論文集, 2004.

3) Stephen Yeo : A Review of Flooding in Apia, Samoa, April 2001, P8, 2001 年 7 月.

4) SOPAC Technical Report/ Capacity Building in Flood Risk Management, P23-P24, 2006.

5) Government of Samoa/Department of Public Works/Flood Study of the Occurrence 15-16th April 2001 Flooding areas of the APIA Township, P5, 2001.

6) Nays:http://ws3-er.eng.hokudai.ac.jp/yasu/hendou/Nays/ index_j.htm

7) 前出 3) P8

8) 前出 4) $\mathrm{P} 41$

9) Terry James P., Kostas Chuk Ray A., Garimella Sitaram: Sediment Deposition rate in the Falefa River basin, Upolu Island, Samoa, J Environ Radioact Vol.86, 2006.

(2007. 9. 30 受付) 